\title{
COGNITIVE DIFFERENCES IN SERVICE QUALITY BETWEEN E-GOVERNMENT USERS AND ADMINISTRATORS
}

\author{
Su-Houn Liu, Chung Yuan Christian University, vandy@im.cycu.edu.tw \\ Yu-hsieh Sung, Development and Evaluation Commission, yhsung@rdec.gov.tw \\ Hsiu-Li Liao, Chung Yuan Christian University, wenlly@im.cycu.edu.tw \\ Ching-Min Liu, Chung Yuan Christian University, chingmin@mis.cycu.edu.tw
}

\begin{abstract}
After Taiwan governments implement it's egovernment portal (MyeGov, www.gov.tw) in 2002 as a means of delivering better information services and resources, building quality service that encourage citizen uptake is becoming an increasing challenge. This paper addresses this issue and examines the quality divide cause by the cognitive difference between users and administrators of the $e$ government portal. To understand what governments need to do to secure successful implementation of comprehensive government service that are relevant to citizens, the services quality of e-government portals are scrutinized through a survey on both its users and administrators. The investigation instrument is based on the conceptual model of service quality proposed by Parasuraman, Zeithaml and Berry. The research finds that the user's intention of re-use the e-Government portal is highly associated with their service quality factors. The research also provides insights for government officials and practitioners to understand and improve e-Government practice by identify major cognitive difference between e-government portal's users and its administrators that cause the low usage rate of the e-government portal.
\end{abstract}

Keywords: e-Government, Service Quality, Government, e-Portal

\section{INTRODUCTION}

World governments increasingly use Internet technology to improve and leverage their services to citizens. As a leading country in ICT (information and communications technology), the Taiwan government strives to improve their service quality and reduce operational costs by adopting advanced information technologies [19]. Taiwan has previously put many public services online through the MyEGov (www.gov.tw) portal created in 2002 by the Research, Development and Evaluation Commission (RDEC). The e-Government's MyEGov portal is intended to be the entry point for all online public services. The portal is designed to provide a focal point for collecting government information and services. However, since different government agencies independently provide information and services on MyEGov, the scattered services cannot satisfy citizen demand for high quality e-government service. Even though more than 80 percent of Taiwanese people are aware of this government website, only 8 percent of them ever access services on MyEGov. Therefore, building quality service that encourages citizen uptake is becoming an increasing challenge for administrators of the MyEGov portal.

This paper addresses this e-government issue and examines the quality divide caused by cognitive differ-ence between users and administrators of the MyEGov portal. To understand what governments need to do to successfully implement comprehensive government service relevant to citizens, the current study scrutinizes MyEGov portal service quality through a survey of both users and administrators. The investigation instrument is based on the conceptual model of service quality proposed by Parasuraman, Zeithaml and Berry [13], [14]. This work proposes a model to assess user's intention of MyEGov portal re-use by identifying major service quality variables of the website and analyses how these variables influence user's intention of re-use for the MyEGov portal. This investigation also provides insights for government officials and practitioners to understand and improve website practice by identifying major cognitive differences (Gaps) between e-government portal's users and its administrators that cause low website usage.

\section{LITERATURE REVIEW}

The SERVQUAL model is proposed by Parasuraman et al. [14] to conceptualize service quality as the relative perceptual distance between customer expectations and evaluations of service experiences and service quality. The SERVQUAL model are composed of five dimensions, including tangibles, reliability, responsiveness, assurance, and empathy. The SERVQUAL model is widely adopted to 
measure e-retailing service quality $[2,12 ; 20]$, online auctions service quality [7], e-banking service quality [18], e-government service quality [22], online travel service quality $[24]$ and web-based service quality $[9$, $10]$.

Traditional service quality might not be sufficient to build the e-service quality dimensions. Based on SERVQUAL model, Santouridis et al. [18] investigates internet service quality and its impact on customer satisfaction in the internet banking context in Greece. All quality dimensions, namely assurance, quality of information, responsiveness, web assistance, empathy and reliability, are proved to be antecedents of customer satisfaction, with reliability having the most significant impact. Jones and Leonard [7] investigate participants into their experience with $\mathrm{C} 2 \mathrm{C}$ e-commerce. The findings indicate SERVQUAL, which includes reliability, responsiveness, assurance, and empathy, all impact satisfaction in $\mathrm{C} 2 \mathrm{C}$ e-commerce. Reliability and responsiveness are found to influence $\mathrm{C} 2 \mathrm{C}$ ecommerce satisfaction, where as they were not found to be an influence in the B2C study. Lee and Lin [11] examine the relationship among e-service quality dimensions and overall service quality, customer satisfaction and purchase intentions of online shopping. The analytical results show that the dimensions of web site design, reliability, responsiveness, and trust affect overall service quality and customer satisfaction. The personalization dimension is not significantly related to overall service quality and customer satisfaction.

Systems quality and information quality are considered an important component of website quality. Separate measures of website information quality and website system quality are consistent with information systems quality models by DeLone and McLean [3] and Spreng et al. (1996). Wangpipatwong, S. et al. [22] examines website quality toward the enhancement of the continued use of e-government portals by e-citizens of Thailand. The research analyzed by using multiple regression analysis to reveal that the three quality aspects, with system quality providing the greatest enhancement, followed by service quality and information quality. Hussein et al. [5] indicate that systems quality, information quality, perceived usefulness, and user satisfaction are significantly correlated with the egovernment system success dimensions in Malaysia. However, the study of Jang et al. (2008) revealed that their community commitment was significantly influenced by their community interaction and the rewards for their activities, but not by information quality and system quality. In the context of e- government, few studies have examined the e-service quality dimensions, system quality and information quality to predict overall service quality, user satisfaction and intention of continued use.

Parasuraman, Zeithaml, and Berry [13] develop a service quality model to indicate that consumer's quality perceptions are influenced by a series of four distinct gaps (Gap $1 \sim$ Gap 4) occurring in organizations (fig. 1). On the service provider's side, these gaps can impede delivery of services that consumers perceive to be of high quality. Perceived service quality is defined in the model (Gap 5).

Gap 1: Difference between consumer expectations and management perceptions of consumer expectations.

Gap 2: Difference between management perceptions of consumer expectations and service quality specifications.

Gap 3: Difference between service quality specifications and the service actually delivered.

Gap 4: Difference between service delivery and what is communicated about the service to consumers.

Gap 5: Difference between consumer expectations and perceptions.

This study attempts to modify and verify conceptual model of service quality to understand user perception of total service quality, user satisfaction and intention of continued use in the e-government context.

\section{RESEARCH METHODOLOGY}

Based on the constructs proposed by Lee and Lin [11], and Delone and Mclean [3], Fig.2 represents the proposed model drawn from the constructs of website design, reliability, responsiveness, personalization, information quality, system quality, total service quality, user satisfaction and intention of continued use. The research model is empirically tested in this study. The definitions of the constructs are provided in Table 1 and discussed in the subsequent discussions.

Based on the above review of literature, an e-service quality model for e-government users is proposed. The hypotheses are formulated as below to address the relationships of service quality, information quality, system quality, total service quality, user satisfaction and intention of continued use: 


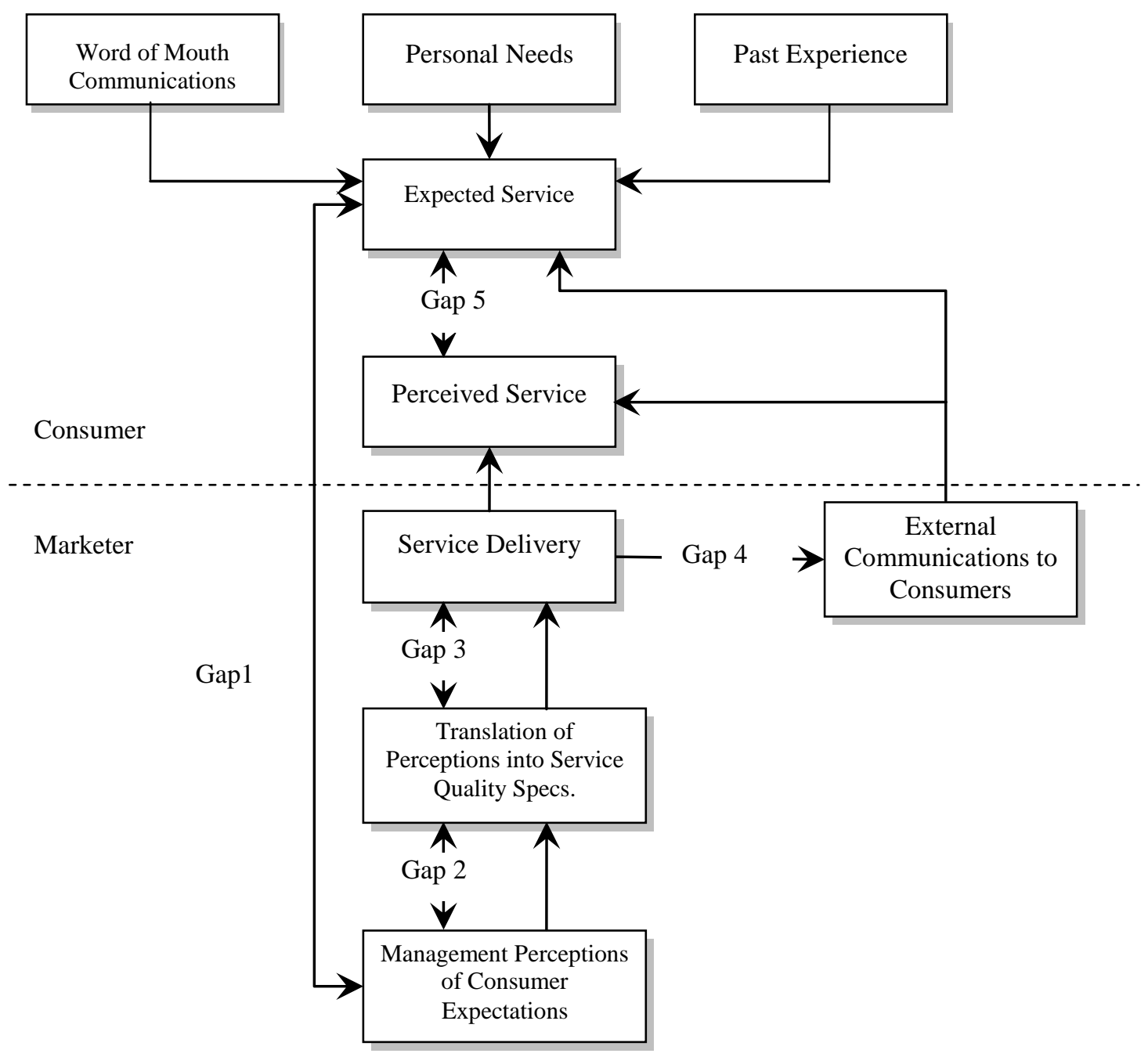

Figure 1. Conceptual Model of Service Quality

H1: Website design, reliability, responsiveness, personalization, information quality and system quality are positively related to total service quality.

$\mathrm{H} 2$ : Website design, reliability, responsiveness, personalization, information quality and system quality are positively related to user satisfaction.

H3: Total service quality is positively related to user satisfaction.

H4: Total service quality and user satisfaction are positively related to intention of continued use.

In order to investigate perception and expectation differences between MyEGov's users and administrators, the current research identifies four service quality constructs to evaluate the differences in this study (fig. 3). Two constructs, "User Perceptions of Service Quality" and "User
Expectations of Service Quality" derive from user surveys that represent users' perception and expectation of websites' service quality. The other two, "Administrator Perceptions of Service Quality", "Administrator Perceptions of User Expectations of Service Quality" derive from administrator surveys that represent administrators' perception of website's service quality and their users' expectation of service quality. Gap1: Position Gap represents the difference between "User Perceptions of Service Quality" and "Administrator Perceptions of Service Quality". Gap2: Implementation Gap represents the difference between "Administrator Perceptions of Service Quality" and "Administrator Perceptions of User Expectations of Service Quality". Gap3: Perception Gap represents the difference between "Administrator Perceptions of User Expectations of Service Quality" and "User Expectations of Service Quality". 


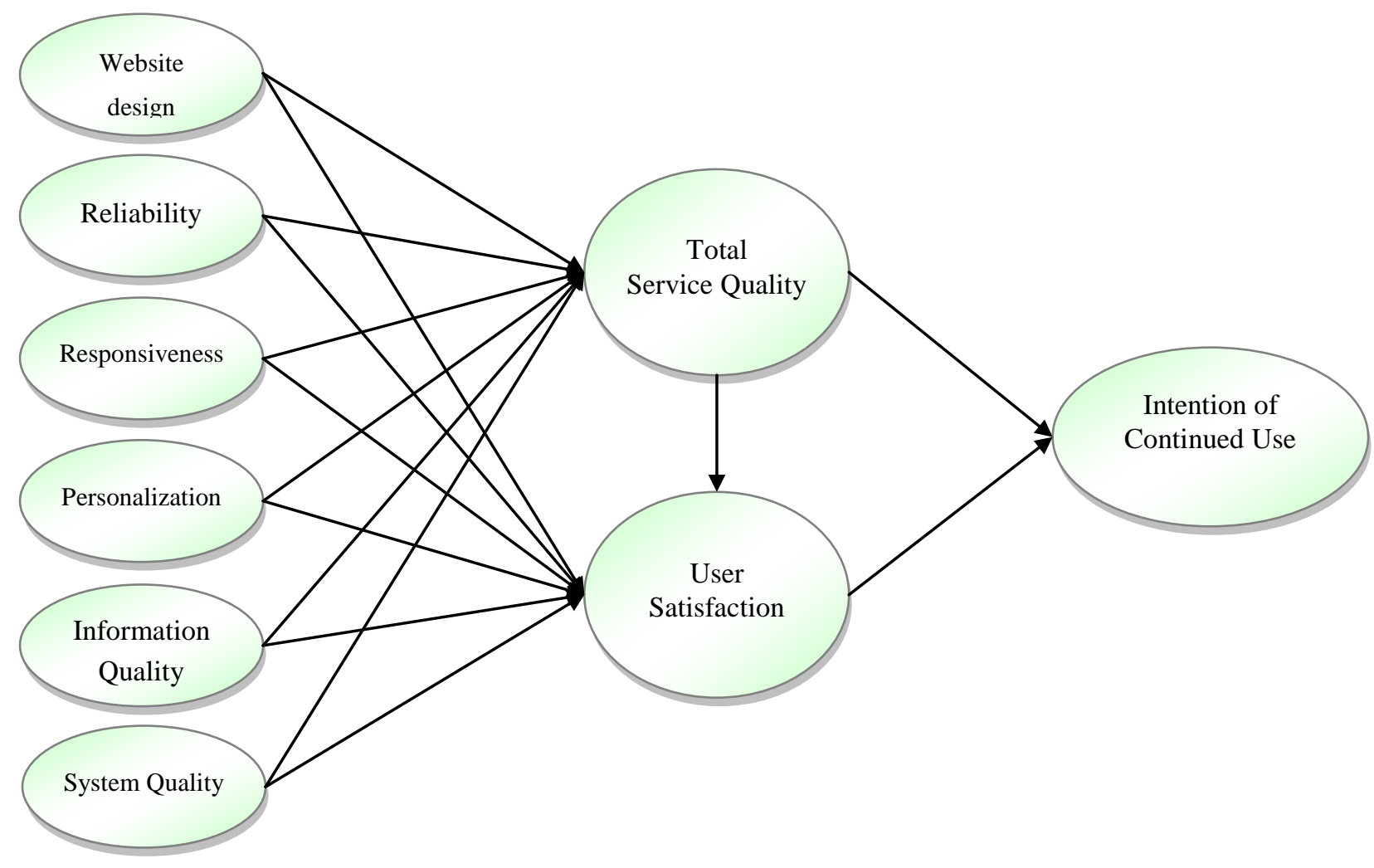

Figure 2. The research model 1

Table 1. Research constructs and definitions

Construct

Website Design

Reliability

Responsiveness

Personalization

Information Quality

System Quality

Total Service Quality

User satisfaction

\section{Definition}

References presents to customers

Degree to which the e-government portal fulfill orders correctly, deliver promptly, and keep personal information secure

Degree to which the e-government portal voluntarily provide services (e.g. customer inquires, information retrieval and navigation speed)

Degree to which the e-government portal provides differentiated services to satisfy specific individual needs

Desired characteristics of the information product. (e.g. accuracy, precision, currency, timeliness, reliability, completeness, conciseness, format and relevance).

Desired characteristics of the information system itself (e.g. convenience of access, flexibility of the system, integration of the system and response time)

Customer perceptions of service quality provided by egovernment portal

Degree of user satisfaction with e-government portal
[11]; [17]

[11]; [8]

[11]; [12]; [21]

[11], [25]

[6], [25] 


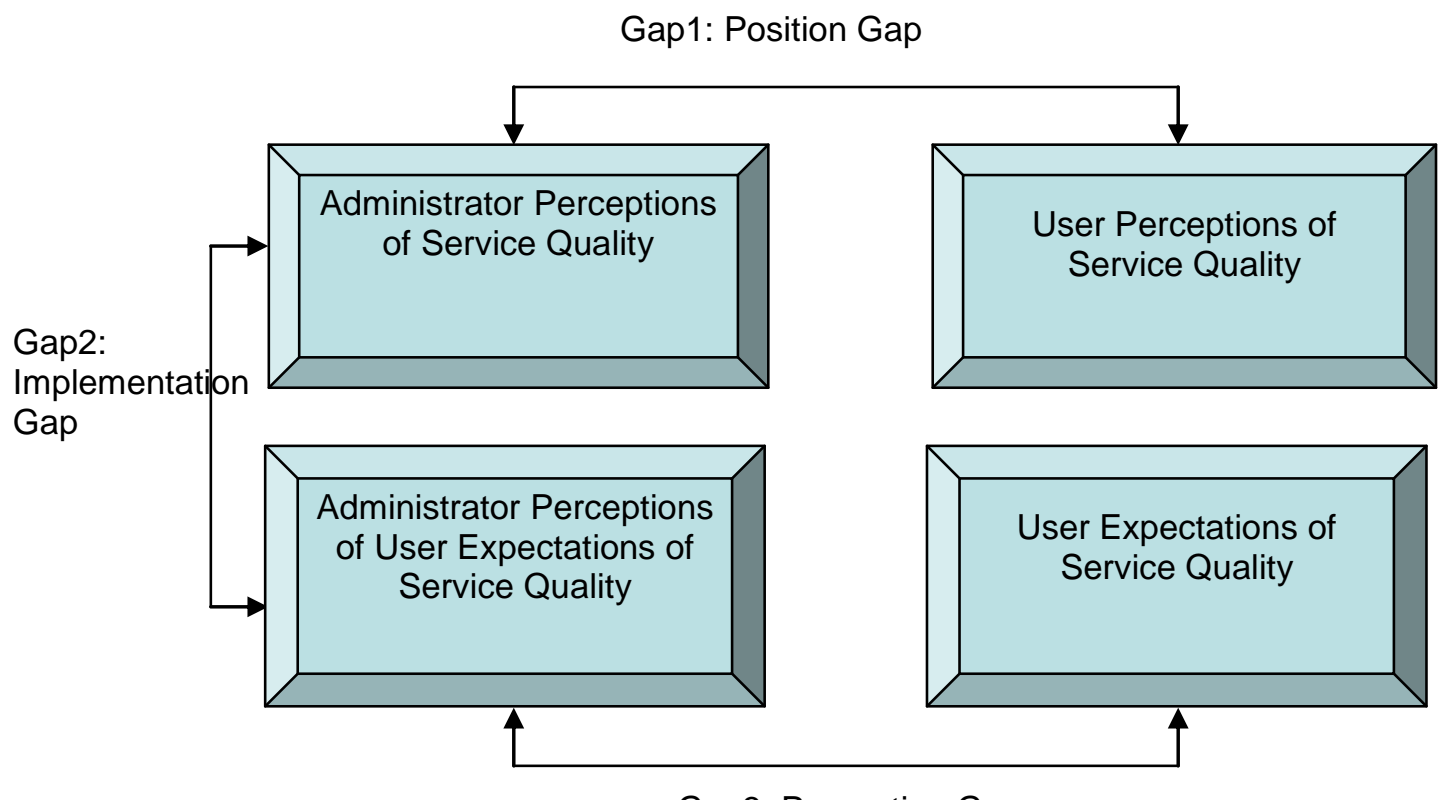

Gap3: Perception Gap

Figure 3. Research model 2

Researchers asked MyEGov's users and administrators to respond to the questionnaire of this study. For MyEGov users, this research randomly selected 500 of them to deliver the user survey questionnaire through e-mail. Among the questionnaires, 257 were returned and 241 were usable, representing a $48.2 \%$ response rate. Among the 241 usable questionnaires, 118 were females (49\%) and 123 were males (51\%). The age of most subjects ranged from 21 to 35 (74.7\%). Most subjects were not students $(73.9 \%)$ and with bachelor degree $(81 \%)$. Researchers asked all eighteen of the MyEGov administrators to complete the administrator survey questionnaire. Sixteen returned and usable questionnaires represent an $88.9 \%$ response rate.

\section{ANALYSIS AND RESULTS}

The current work measured the research model using the partial least squares (PLS) structural modeling analysis approach. The PLS is appropriate for predicting highly complex [1] models and maximizing the variance explained for the constructs in a model [16]. Table 2 presents the composite reliability (CR), average variance extracted (AVE), and Cronbach's $\alpha$. All reliability measures were 0.7 or above. The pha-level of the sample indicates a reasonable level of reliability, revealing adequate internal consistency.

Table 3 shows each variable's square root of AVE and intercorrelations, ranging from 0.491 to 0.846 . Convergent validity of the instrument is appropriate when the constructs have an average variance extracted (AVE) of at least 0.5 [4]. The AVE for every construct is larger than the correlation between the construct and other constructs in the model.

Web design $(\beta=0.282, p<0.01)$, personalization $(\beta=-$ $0.118, \mathrm{p}<0.1)$, information quality $(\beta=0.354, \mathrm{p}<0.01)$ and system quality $(\beta=0.256, p<0.01)$ significantly af-fect total service quality $(\mathrm{R} 2=0.627)$. Web design $(\beta=0.184, p<0.01)$, Responsiveness $(\beta=0.159, p<0.05)$ and system quality $(\beta=0.126, p<0.05)$, significantly influence user satisfaction $(\mathrm{R} 2=0.841)$. Total service quality $(\beta=0.390, p<0.01)$ and user satisfaction $(\beta=0.457, p<0.01)$ have significant, direct effect on Intention of continued use (R2=0.661) (fig. 4). 
Table 2. Construct reliabilities and average variance extracted

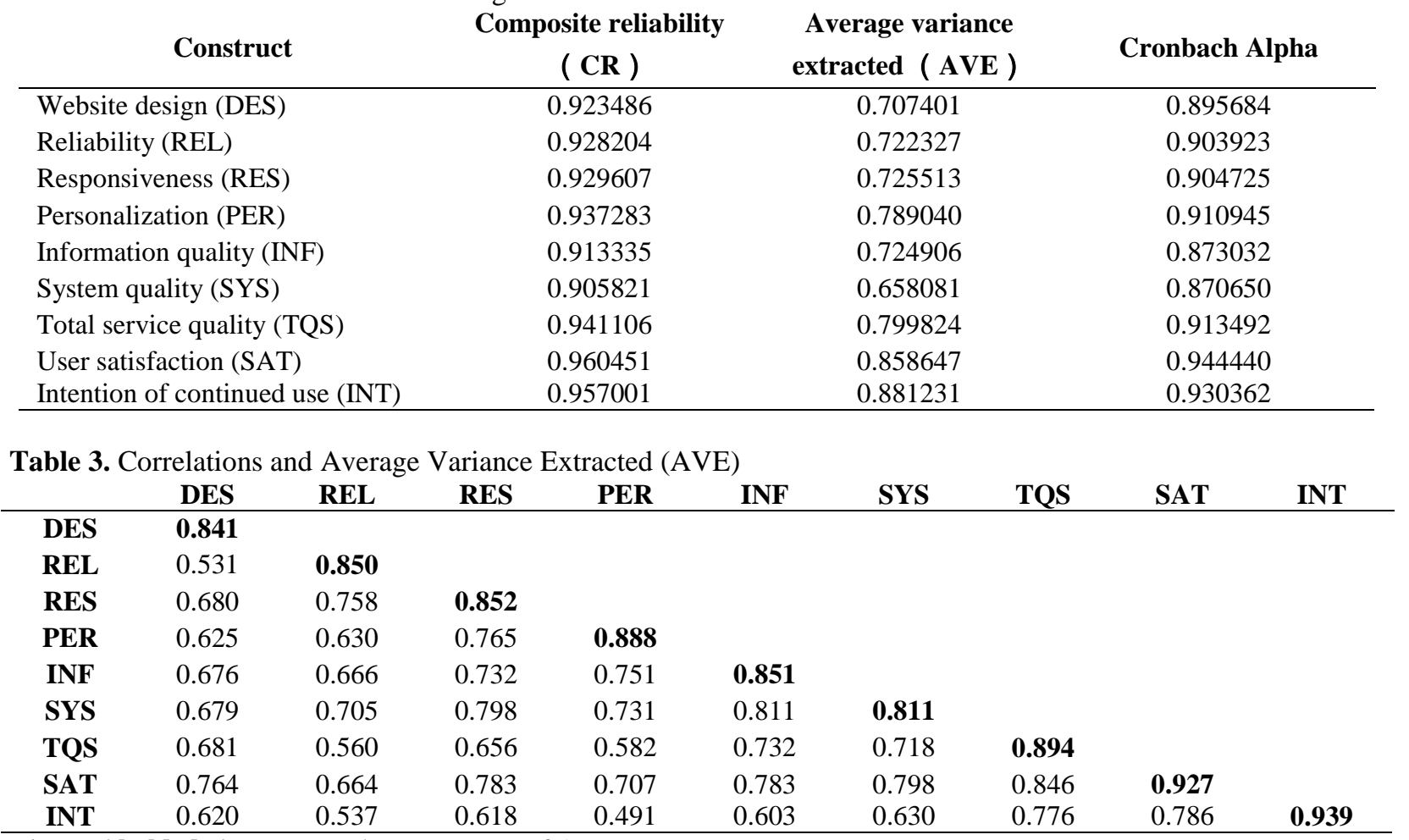

Diagonal bolded elements are the square root of AVE.

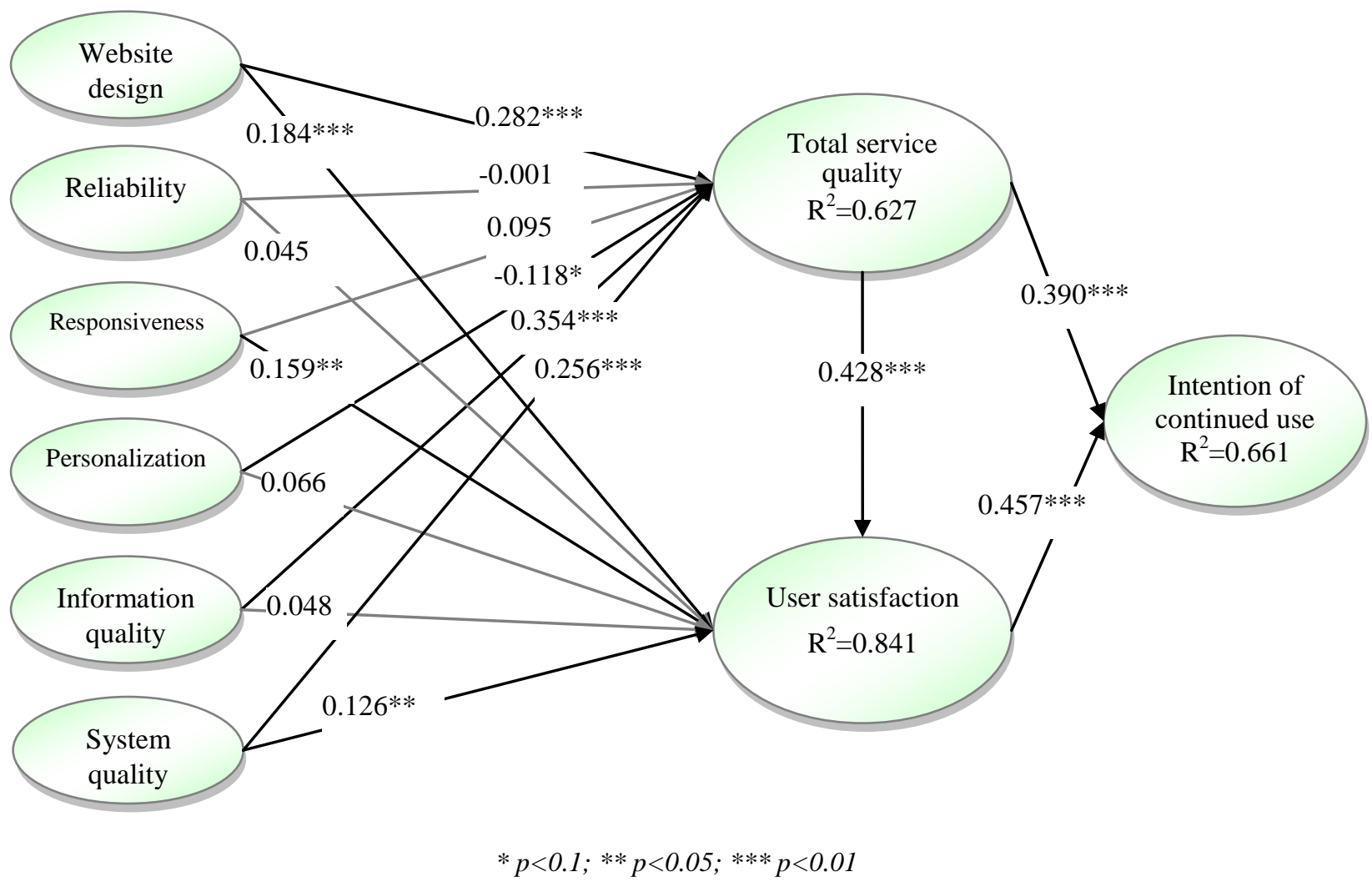


Figure 4. Research model results

Table 4. Mann-Whitney U test - Gap1: Position Gap

\begin{tabular}{lccc}
\multicolumn{1}{c}{ Construct } & Mann-Whitney U & Z-test & P-value \\
\hline Website design & 1340.00 & -2.047 & $0.041^{*}$ \\
Reliability & 999.00 & -3.234 & $0.001^{*}$ \\
Responsiveness & 1153.50 & -2.696 & $0.007^{*}$ \\
Personality & 953.50 & -3.394 & $0.001^{*}$ \\
Information quality & 1410.50 & -1.806 & 0.071 \\
System quality & 1398.00 & -1.841 & 0.066 \\
\hline$*$ p $<0.05$ & &
\end{tabular}

Table 5. Mann-Whitney U test - Gap2: Implementation Gap

\begin{tabular}{lccc}
\multicolumn{1}{c}{ Construct } & Mann-Whitney U & Z-test & P-value \\
\hline Website design & 58.00 & -2.653 & $0.008^{*}$ \\
Reliability & 45.00 & -3.145 & $0.002^{*}$ \\
Responsiveness & 66.00 & -2.351 & $0.019^{*}$ \\
Personality & 78.50 & -1.879 & 0.060 \\
Information quality & 52.50 & -2.867 & $0.004^{*}$ \\
System quality & 69.00 & -2.237 & $0.025^{*}$ \\
$* \mathrm{p}<0.05$ & & &
\end{tabular}

Table 6. Mann-Whitney U test - Gap3: Perception Gap

\begin{tabular}{lccc}
\multicolumn{1}{c}{ Construct } & Mann-Whitney U & Z-test & P-value \\
\hline Website design & 344.00 & -5.513 & $0.000^{*}$ \\
Reliability & 111.50 & -6.321 & $0.000^{*}$ \\
Responsiveness & 406.00 & -5.297 & $0.000^{*}$ \\
Personality & 416.00 & -5.264 & $0.000^{*}$ \\
Information quality & 398.50 & -5.335 & $0.000^{*}$ \\
System quality & 298.00 & -5.661 & $0.000^{*}$ \\
\hline
\end{tabular}

$* \mathrm{p}<0.05$

\section{CONCLUSION AND MANAGEMENT IMPLICATIONS}

Researchers have widely accepted the importance of system quality as a critical factor for user's intention of re-using the system.. Based on Results of this study corroborate all three hypotheses related to the relation-ship of Total Service Quality, User Satisfaction and Intention to Continued Usage. In this study, both Total Service Quality and User Satisfaction positively relate to user's intention to continue use of MyEGov. Empiri-cal findings from this study also show that the casual relationship between Total Service Quality and the out-come variable (User Satisfaction) are as predicted in the previous literature.

Existing IS-related literature finds a variety of quality factors (Website design, Reliability, Respon-siveness, Personalization, Information Quality, System Quality) that affect a website's total service quality and user satisfaction in general. However, this study finds that fore-government portal usage, main system quality variables may not relate to each other as previous stud-ies propose. Empirical findings from this study show that Website Design, Personalization, Information Qual-ity, System Quality have significant relationship with Total Service Quality. Among them, Personalization actually has a negative relationship with users' percep-tions of the website's Total Service Quality.

We believe the relationships between various qual-ity variables and Total Service Quality may indicate that most users use MyEGov as a government information retrieval website only. In another words, users visit MyEGov to browse information interesting to them, instead of conducting online transactions with govern-ment offices. So Reliability, Responsiveness factors of the website are irrelevant for these users. For users wanting to conduct online transactions with government, Personalization of the portal may be very important. But for users who just want to browse various government related information, Personalization may limit the kind of information 
they can get from the website, so it has a negative relationship with users' perceptions of the website's Total Service Quality. The quality derived from a good website design, information and system quality may be more important to these users.

For User Satisfaction of the e-government portal, findings of this study indicate that Website Design, Re-sponsiveness, System Quality have significant positive impacts. Among them, Website Design is the most critical factor. We believe these relationships may indi-cate that most users recognize MyEGov as an information broker rather than an information provider. That is, even though users recognize that Information Quality has positive impact on their service quality per-ceptions, they do not recognize MyEGov as responsible for good or poor quality website information. They recognize MyEGov as responsible for the operation and system side only. Therefore, quality variables related to MyEGov's operation and system relate to User Satisfac-tion.

Table 7. Service Gaps of MyEGov

\begin{tabular}{|c|c|c|c|}
\hline $\begin{array}{l}\text { User Perceptions } \\
\text { of Service Quality }\end{array}$ & $\begin{array}{l}\text { Administrator } \\
\text { Perceptions } \\
\text { of Service Quality }\end{array}$ & $\begin{array}{l}\text { Administrator } \\
\text { Perceptions of } \\
\text { User Expectations } \\
\text { of Service Quality }\end{array}$ & $\begin{array}{l}\text { User Expectations } \\
\text { of Service Quality }\end{array}$ \\
\hline $\begin{array}{l}\text { Website design } \\
\text { Information Quality } \\
\text { System Quality } \\
\text { Responsiveness } \\
\text { Reliability } \\
\text { Personalization }\end{array}$ & $\begin{array}{l}\text { Reliability } \\
\text { Responsiveness } \\
\text { Information Quality } \\
\text { Website design } \\
\text { Personalization } \\
\text { System Quality }\end{array}$ & $\begin{array}{l}\text {-Reliability } \\
\text { Information Quality } \\
\text { Website design } \\
\text { Responsiveness } \\
\text { System Quality } \\
\text { Personalization }\end{array}$ & $\begin{array}{l}\text { Website design } \\
\text { Information Quality } \\
\text { System Quality } \\
\text { Reliability } \\
\text { Responsiveness } \\
\text { - Personalization }\end{array}$ \\
\hline
\end{tabular}

Since users recognize MyEGov as an Information Broker and use it merely to retrieve government information, it is interesting to further investigate whether the website's administrators recognize this and implement MyEGov according to user's expectation. Based on the results, the answer is "They did not". In this study, all the differences between "User Perceptions of Service Quality", "Administrator Perceptions of Service Quality”, “Administrator Perceptions of User Expectations of Service Quality" and "User Expectations of Service Quality" are significant. For example, the administrators recognize Reliability as the most critical factor both in their perceptions of user expectations of service quality and on MyEGov's service quality. But on the user side, users do not think MyEGov is reliable (it ranks No. 5 on the list); they also do not think the reliability of MyEGov is very important (it ranks No. 4 on the list). We believe that these results have important implications for administrators and their management of MyEGov. The administrators of MyEGov want to construct an integrated government service access point (a Virtual Government) on the web. But from users' point of view, they browse MyEGov looking for government information but not services.
Understanding the nature and determinants of users' intention to continued usage is a necessary and critical starting point in developing and implementing egovernment portal service. When administrators believe they are running an integrated website for government service, while their users do not believe and expect such, administrators cannot expect higher user's intention to continue use of MyEGov. This study therefore suggests that administrators focus on eliminating the gaps between their's and user's perceptions of MyEGov. This can be done by either positioning the website in a more practical position (provide government information instead of services) or educate their users to trust and accept online government service on their website.

\section{REFERENCES}

1. Barclay, D. W., Higgins, C. A., and Thompson, R. (1995). The Partial Least Squares (PLS) approach to causal modeling: Personal computer adoption and use as an illustration. Tech. Stud., 2(2), 285-309. 
2. Barnes, S. and R. Vidgen. (2002). An Integrative Approach to the Assessment of E-commerce Quality. Journal of Electronic Commerce Research, 3(2), 114-127.

3. DeLone, W.H. and E.R. McLean. (1992). Information system success: the quest for the dependent variable. Information System Research, 6, 60-95.

4. Fornell, C., D. F. Larcker. (1981). Evaluating structural equation models with unobservable variables and measurement error. Journal Marketing Research, 18, 39-50.

5. Hussein, R., Karim, N. S. A., and Selamat, M. H. (2007). The Impact of Technological Factors on Information Systems Success in the ElectronicGovernment Context, Business Process Management Journal, 13(5), 613-628.

6. Iivari, J. (2005). An empirical test of the DeLone-McLean model of information system success. ACM SIGMIS Database, 36(2), 8-27.

7. Jones, K. and Leonard, L. N K. (2007). Consumer-to-Consumer Electronic Commerce: A Distinct Research Stream. Journal of Electronic Commerce in Organizations, 5(4), 3955.

8. Kim, J. and J. Lee. (2002). Critical Design Factors for Successful E-commerce Systems. Behaviour \& Information Technology, 21(3), 185-199.

9. Kuo, Y.F. (2003). A Study on Service Quality of Virtual Community Web Sites. Total Quality Management, 14(4), 461-473.

10. Kuo, T., Lu, L. Y., Huang, C. H., and Wu, G. C. (2005). Measuring Users' Perceived Portal Service Quality: An Empirical Study. Total Quality Management \& Business Excellence, 16(3), 309-324.

11. Lee, G. G. and H. F. Lin. (2005). Customer Perceptions Of E-service Quality In Online Shopping. International Journal of Retail and Distribution Management, 33(2), 161-176.

12. Lin, S. F. and Lee G.G. (2006). A Study of Service Quality Evaluation Model for Virtual Knowledge Communities. EC Research, 4(2), 221-234.

13. Parasuraman, A., V.A. Zeithaml and L.L. Berry. (1985). A Conceptual Model of Service Quality and Its Implications for Future Research. Journal of Marketing, 49, 41-50.

14. Parasuraman, A., V.A. Zeithaml and L.L. Berry. (1988). SERVQUAL: a multiple item scale for measuring customer perceptions of service quality. Journal of Retailing, 64(1), 12-40.

15. Parasuraman, A., V.A. Zeithaml and A. Malhotra. (2005). E-S-QUAL: A Multiple-Item
Scale for Assessing Electronic Service Quality. Journal of Service Research, 7(3), 213-233.

16. Plouffe, C. R.., Hulland, J. S., Vandenbosch, M. (2001). Research report: richness versus parsimony in modeling technology adoption decisions-understanding merchant adoption of a smart card-based payment system. Information systems research, 12(2), 208-222.

17. Santos, J. (2003). E-service Quality: A Model of Virtual Service Quality Dimensions. Managing Service Quality, 13(3), 233-246.

18. Santouridis, I., Trivellas, P., and Reklitis, P. (2009). Internet Service Quality and Customer Satisfaction: Examining Internet Banking in Greece. Total Quality Management \& Business Excellence, 20(2), 223-237.

19. Sung, Yu-hsieh. (2007). Research and Implementation of e-government, Sun Yun Suan Academic Foundation.

20. Swaid, S. I and Wigand, R. T. (2009). Measuring the Quality of E-Service: Scale Development And Initial Validation. Journal of Electronic Commerce Research, 10(1), 13-28.

21. Wang M. (2003). Assessment of E-Service Quality via E-Satisfaction in E-Commerce Globalization. The Electronic Journal on Information Systems in Developing Countries, 11(10), 1-4.

22. Wangpipatwong, S., Chutimaskul, W., and Papasratorn, B. (2009). Quality En Quality Enhancing the Continued Use of E-Government Web Sites: Evidence from E-Citizens of Thailand. International Journal of Electronic Government Research. International Journal of Electronic Government Research, 5(1), p. 19-35.

23. Wolfinbarger, M. and Gilly, M. G. (2003). eTailQ: dimensionalizing, measuring and predicting etail quality. Journal of Retailing, 79(3), 183-198.

24. Van Riel, A., J. Semeijn and P. Pauwels. (2004). Online Travel Service Quality: the Role of PreTransaction Services. Total Quality Management, 15(4), 475-493.

25. Zhu, F. X., Wymer, W. and Chen, I. (2002). ITbased services and service quality in consumer banking. International Journal of Service Industry Management, 13(1), 69-90. 